\title{
ANALISIS PEMAHAMAN KONSEP PADA MATERI SISTEM PERSAMAAN LINEAR TIGA VARIABEL BERDASARKAN TEORI APOS
}

\author{
Ida Silfia ${ }^{1}$, Yuniar Ika Putri Pranyata ${ }^{2}$ \\ ${ }^{1,2}$ Program Studi Pendidikan Matematika, Universitas PGRI Kanjuruhan Malang \\ Email: idasilfia26@gmail.com
}

\begin{abstract}
Abstrak:
Tujuan dalam penelitian ini adalah untuk mendeskripsikan hasil analiss kemampuan pemahaman konsep peserta didik terhadap materi Sistem Persamaan Linier Tiga Variabel (SPLTV) berdasarkan teori APOS (aksi, proses, objek, dan skema). Penelitian ini dilakukan pada tiga peserta didik kelas X MA Miftahul Huda Kepanjen dengan kemampuan (A) tinggi, (B) sedang, dan (C) rendah. Hasil dari analisis menunjukan bahwa peserta didik dengan kemampuan tinggi mampu memiliki semua tahapan pada APOS. Peserta didik dengan kemampuan sedang tidak memenuhi pada tahapan proses. Sedangkan peserta didik berkemampuan rendah hanya mampu mencapai pada tahapan aksi. Dari uraian tersebut dapat disimpulkan bahwa tingkat kemapuan peserta didik juga sangat erat kaitanya dengan tingkat pemahaman konsep terhadap materi yang diberikan. Oleh karena itu peneliti menyarankan kepada guru untuk memperhatikan proses penyampaian materi pada pembelajaran matematika.
\end{abstract}

Kata Kunci: Pemahaman Konsep, SPLTV, Teori APOS

\begin{abstract}
:
This research aims to describe the analysis of students to understand the concept of the Three Variable Linear Equation System (SPLTV) based on the APOS theory (Action, Process, Object and Schema). This research did in the three students class $\mathrm{X}$ of MA Miftahul Huda Kepanjen. With students high (A), medium (B) and low ability categories(C). The results of the study show that highly capable subjects have an understanding of the stages of APOS (action, processes, objects and schemes). Subjects who are capable of having did't understanding at the stage of process. While low-ability subjects have an understanding of the stages of action. In this description get node action the students tight with to understand the concept of the materi. So, researcher proposition of the teacher for notice the process materi in this study mathematics.
\end{abstract}

Keywords: Understanding of Concepts, SPLTV, APOS Theory

\section{Pendahuluan}

Matematika merupakan materi pelajaran mendasar yang secara luas diterapkan pada kehidupan sehari-hari. Melalui matematika, peserta didik diharapkan mampu berfikir kreatif, sistematis, dan logis dalam menyelesaikan suatu permasalahan (Lestari, 2015). Meskipun penting matematika dianggap sebagian besar peserta didik merupakan ilmu yang sulit, membosankan, abstrak, dan cenderung untuk dihindarinya (Najlasari, 2019). Menurut (Wahyuningsih et al., 2019) menyatakan bahwa beberapa faktor penyebab matematika tidak disukai peserta didik adalah penjabaran disetiap permasalahan terlalu rumit, sulit menghafal dan memahami rumus-rumus sehingga berdampak pada pemahaman konsep.

Berdasarkan hasil wawancara secara online yang dilakukan pada peserta didik MA Miftahul Huda Kepanjen proses pembelajaran matematika pada masa pandemi covid-19 yang diajarkan oleh guru masih belum maksimal. Pada saat kegiatan pembelajaran berlangsung tidak semua peserta didik mau memperhatikan dan memahami materi dengan sungguhsungguh. Akibatnya penguasan konsepkonsep matematika pada peserta didik masih lemah. Berdasarkan hasil Ujian Tengah Semester Ganjil menunjukan bahwa peserta didik kelas X MA Miftahul Huda Kepanjen tidak menerima pembelajaran dengan baik. Pernyataan ini 
dapat ditunjukan pada lembar jawaban peserta didik terkait latihan soal Sistem Persamaan Linier Tiga Variabel (SPLTV) yang telah diberikan. Sebagian besar peserta didik tidak mengetahui jika Sistem Persamaan Linier Tiga Variabel (SPLTV) merupakan suatu sistem yang memiliki tiga variabel dan mempunyai penyelesaian dengan tiga macam penyelesaian yaitu (1) substitusi, (2) eliminasi, dan (3) campuran. Selain itu sebagian peserta didik kurang memahami bagaimana penggunaan cara penyelesaian tersebut ke dalam soal cerita yang diberikan oleh guru. Dari beberapa uraian tersebut membuktikan bahwa masih terdapat peserta didik yang kurang memahami konsep dengan baik.

$$
\text { Pemahaman konsep pada }
$$

matematika akan lebih bermakna jika peserta didik mampu menemukannya sendiri tanpa adanya unsur paksaan, hafalan, atau mengikuti algoritma rumus yang diberikan oleh guru (Harta et al., 2014). Keberhasilan dalam pemahaman konsep matematika khususnya pada materi Sistem Persamaan Tiga Variabel (SPLTV) sangat perlu diupayakan baik dengan mengevaluasi pemikiran mereka maupun mengembangkan keterampilan penalaran matematika (Harta et al., 2014). Dalam (Ningsih \& Rohana, 2018) pemahaman konsep merupakan kemampuan mengingat sesuatu setelah mengetahui hal tersebut. Sedangkan menurut (Alifiani, 2017) memahami konsep matematika berati peserta didik mampu mengetahui semua terkait definisi, ciri khusus, maupun isimateri beserta penyelesaian-penyelesaian soal terkait. Peserta didik paham jika mampu menguasai konsep maupun prosedur penyelesaian dan menghubungkan dengan konsep matematika (Ningsih \& Rohana, 2018).

Tingkat pemahaman konsep pada peserta didik dapat diukur menggunakan salah satu teori yaitu APOS. Teori APOS (aksi, proses, objek, skema) merupakan salah satu teori konstruktivis dalam pembelajaran matematika (Mulyono, 2011). Perkembangan peserta didik menurut teori APOS dapat dilihat dari 4 karakteristik yang berbeda diantaranya adalah aksi, proses, objek, dan skema. Berdasarkan karakteristik aksi, peseta didik mampu menggunakan rumus, algoritma, dan contoh yag diberikan oleh guru. Berdasarkan karakteristik proses, peserta didik belum memahami konsep akan tetapi mampu merefleksikan, menjelaskan, dan membalik langkah-langkah peyelesaian. Berdasarkan karakteristik objek, peserta didik mampu melakukan aksi pada suatu objek menjadi proses sehingga dapat memahami sifat-sifat suatu konsep. Pada karakteristik terakhir yaitu skema, peserta didik mampu menghubungkan aksi, proses, dan objek pada konsep dengan konsep yang lainnya sehingga mampu menggunakan berbagai rumus atau aturan yang perlu digunakan.

Dengan menggunakan teori APOS, menuntut peserta didik untuk menguasai konsep pada materi Sistem Persamaan Linier Tiga Variabel dikarenakan masih berkaitan dengan pemecahan masalah konseptual (Fuadi et al., 2016). Berikut ini merupakan penelitian teori APOS yang pernah diterapkan untuk mengetahi tingkat pemahaman konsep peserta didik pada materi tertentu antara lain: dalam penelitian (Fitrianda, 2013) diperoleh bahwa tingkat pemahaman peserta didik pada materi relasi dan fungsi kelas VIII A di SMP Negeri 4 Jember sudah mencapai tahap skema akan tetapi belum mencapai tahap objek dikarenakan peserta didik belum mengusai materi namun bisa menjalankan tahap aksi, proses, untuk menyelesaikan persoalan pada tahap skema. Peningkatan kemampuan matematis peserta didik dengan menggunakan model pembelajaran APOS lebih baik dari pada menggunakan model pembelajaran konvensional (Lestari, 2015). Selain itu, menurut penelitian yang dilakukan (Ningsih \& Rohana, 2018) menyatakan bahwa tingkat pemahaman konsep mahasiswa pada materi persamaan differensial hanya mampu pada tahap aksi, dikarenakan kesulitan dalam memilih prosedur penyelesaiannya. Berdasarkan uraian diatas menunjukan bahwa teori APOS dapat digunakan guna mengukur atau menganalisis tingkat pemahaman konsep peserta didik pada suatu materi. Oleh karena itu, peneliti bermaksud untuk melakukan penelitian dalam pembelajaran matematika mengenai "Analisis 
Pemahaman Konsep Pada Materi Sistem Persamaan Tiga Variabel Berdasarkan Teori APOS di MA Miftahul Huda Kepanjen".

\section{Metode Penelitian}

Metode penelitian yang digunakan yaitu pendekatan kualitaif dengan jenis penelitian deskriptif yang menggunakan tiga subjek dari peserta didik kelas X MA Miftahul Huda Kepanjen. Subjek penelitian tersebut diantaranya yaitu berkemampuan rendah (2) berkemampuan sedang (3) dan berkemampuan tinggi. Teknik pemilihan subjek menggunkan purposive sampling sehingga peneliti mencari sendiri subjek yang akan digunakan dalam penelitian disesuaikan dengan tujuan penelitian. Dalam penelitian ini mengguakan triangulasi teknik dalam pengambilan datanya, diantaranya yaitu tes untuk melihat kemampuan peserta didik dalam pemahaman konsep, wawancara, dan dokumentasi dari berbagai literatur penelitian yang serupa. Tes terdiri dari 4 soal, yang diberikan guna mengukur tingkat pemahaman konsep peserta didik pada materi Sistem Persamaan Linier Tiga Variabel (SPLTV). Sesuai dengan (Jeheman et al., 2019) instrument pokok yang dapat digunakan dalam penelitian ini yaitu lembar tes kemampuan pemahaman konsep berdasarakan teori APOS dengan tingkat kesulitan soal yang berbeda-beda. Wawancara pada penelitian ini meliputi reduksi data, penyajian data, dan penarikan kesimpulan. Dan pada tahap dokumentasi teknik pengambilan data dilakukan dengan cara membaca dari beberapa literatur penelitian serupa. Oleh karena itu untuk menguji keabsahan data peneliti menggunakan triangulasi teknik.

Adapun tahapan dalam pelaksanaan atau perancangan peneliti menggunakan triangulasi teknik adalah sebagai berikut:

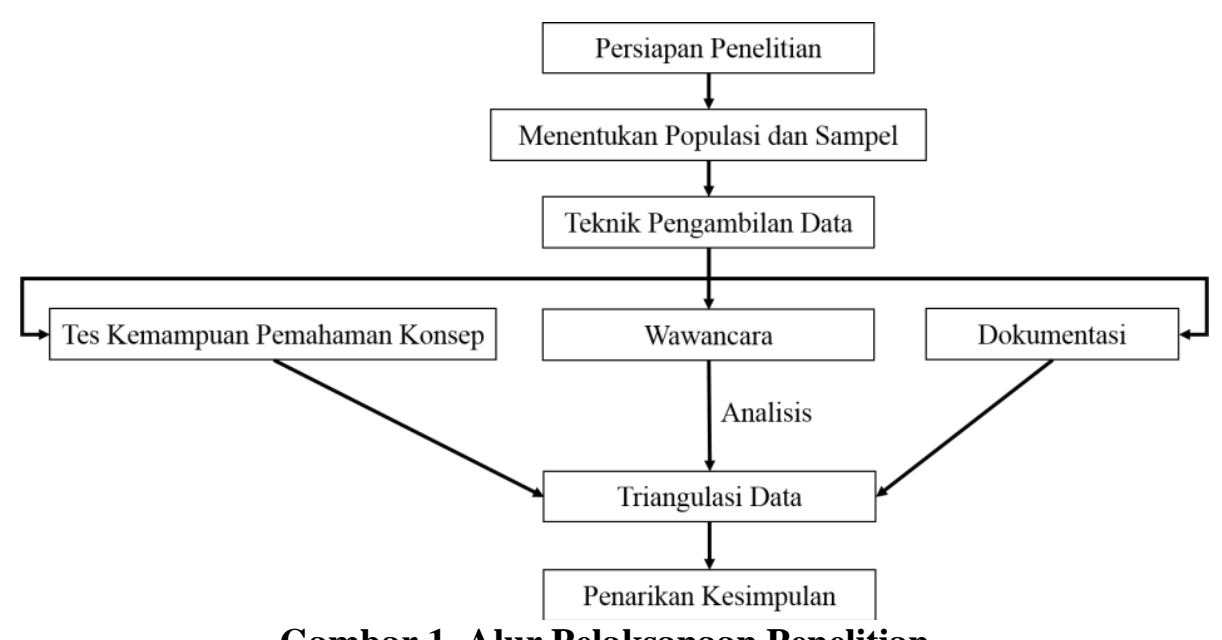

Gambar 1. Alur Pelaksanaan Penelitian

\section{Hasil dan Pembahasan \\ Hasil}

Hasil analisis yang telah dicapai dalam tingkat pemahaman konsep materi Sistem Persamaan Linier Tiga Variabel (SPLTV) berdasarkan teori APOS yang dilakukan pada peserta didik kelas X MA Miftahul Huda adalah sebagai berikut:

1. Ketiga subjek yang dipilih memiliki tingkat pemahaman konsep yang berbeda-beda.

2. Subjek A yaitu peserta didik dengan kemampuan tinggi telah memenuhi kriteria APOS dalam pemahaman konsep materi SPLTV.

3. Subjek B yaitu peserta didik dengan kemampuan sedang mampu memenuhi kriteria aksi, objek, dan skema. Subjek ini belum memenuhi kriteria proses, akan tetapi masih mampu menyelesaikan soal lain.

Subjek C yaitu peserta didik dengan kemampuan rendah hanya mampu memenuhi kriteria aksi. 


\section{Pembahasan}

Pemahaman konsep menurut (Mulyono, 2011) berdasarkan teori APOS dapat diuraikan bahwa: pada tahap aksi peseta didik mampu mendefinisikan pengertian SPLTV menggunakan bahasa sendiri, mampu meunjukan contoh dan bukan contoh SPLTV, dan dapat mensubstitusikan nilai tertentu dedalam SPLTV. Pada tahap proses, peserta didik dapat menemukan himpunan penyelesaian SPLTV serta mampu menerapkan cara lain dalam penyelesaiannya. Pada tahap objek peserta didik mampu menyelesaikan dan menemukan himpunan penyelesaian SPLTV yang diberikan. Dan pada tahap yang terakhir adalah skema, peserta didik mampu merubah kalimat dalam soal cerita menjadi suatu persamaan matematis yang dapat diselesaikan menggunakan prosedurprosedur sehingga didapatkan suatu himpunan penyelesaian. Berikut ini adalah hasil analisis jawaban peserta didik dalam pemahaman konsep berdasarkan teori APOS:

Peserta didik berkemampuan tinggi mampu mencapai semua tahap APOS. Peserta didik mampu menjawab semua soal dengan benar, hal ini dapat dibuktikan dengan gambar di bawah ini.

\section{SPlv (Sisten Persancean Linier Tign Varidale)

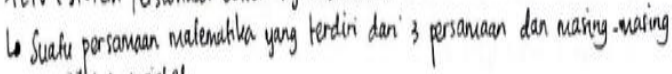 menultis 3 varabel.}

\section{Gambar 2. Subjek A Menunjukan Aksi}

Menurut (Mulyono, 2011) menyatakan bahwa pada tahap aksi peserta didik mampu mengikuti atau memahami contoh yang diberikan dan mengetahui hal-hal mendasar terkait materi yang diberikan seperti definisi. Berdasarkan jawaban yang diperoleh, semua objek memenuhi karakteristik dari tahap aksi. Dari hasil wawancara, peserta didik mampu memahami hal-hal mendasar dikarenakan mampu menanggap dan menghafal inti materi yang disampaikan oleh guru.

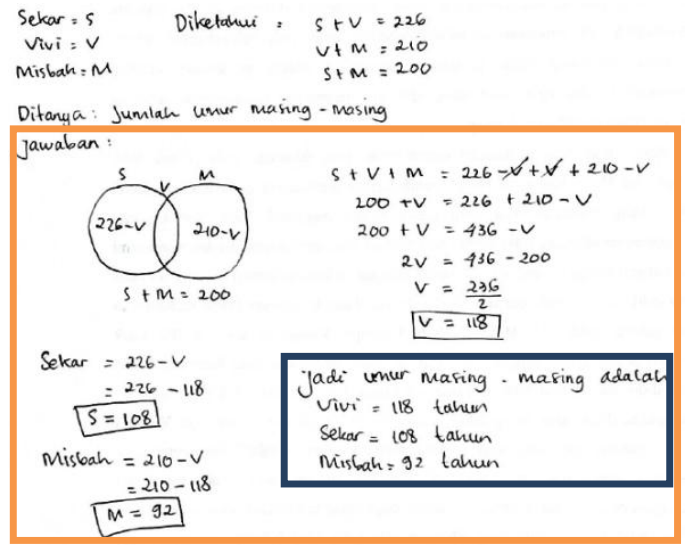

Gambar 3. Subjek A Mampu Menemukan Himpunan Penyelesaian dan Menggunakan Cara Lain

Berdasarkan hasil wawancara, subjek A mampu menemukan himpunan penyelesaian pada soal dengan menggunakan cara lain atau menggunakan metode yang tidak diajarkan. Peserta didik tersebut mengakui jika pada soal yang diberikan hanya memahami dan bisa menggunakan penyelesaian seperti pada gambar. Berdasarkan (Mulyono, 2011). selain pada tahap aksi dan proses, subjek A juga memenuhi tahap objek serta skema.

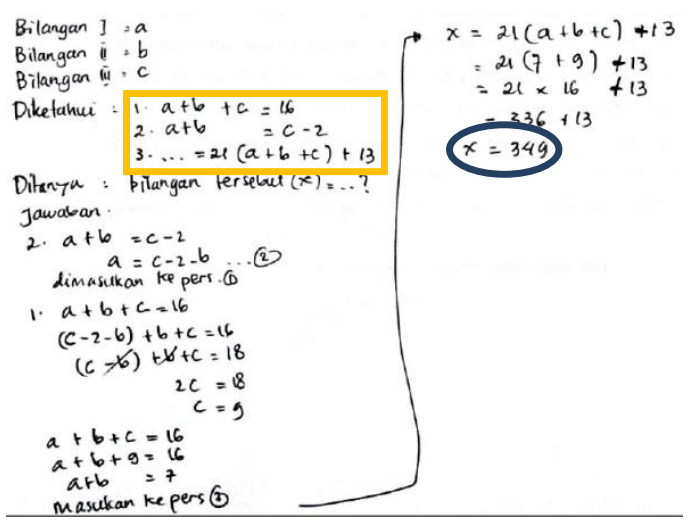

\section{Gambar 4. Subjek A Mampu Menemukan Himpunan Penyelesaian dan Membuat Model Matematika SPLTV}

Pada gambar di atas dapat diketahui bahwa peserta didik mampu menemukan penyelesaiannya serta mampu menuliskan dalam bentuk model 
matematika. Menurut hasil wawancara, peserta didik tersebut tidak mengalami kesulitan sama sekali daam penyelesaian soal. Hal ini dikarenakan materi yang diberikan oleh guru sudah tersampaikan dengan jelas.

Peserta didik berkemampuan sedang cenderung bisa mengerjakan semua soal dan mampu memahami hal-hal mendasar terkait SPLTV. Akan tetapi peserta didik tersebut tidak bisa menggunakan cara lain yang tidak diberikan oleh guru.

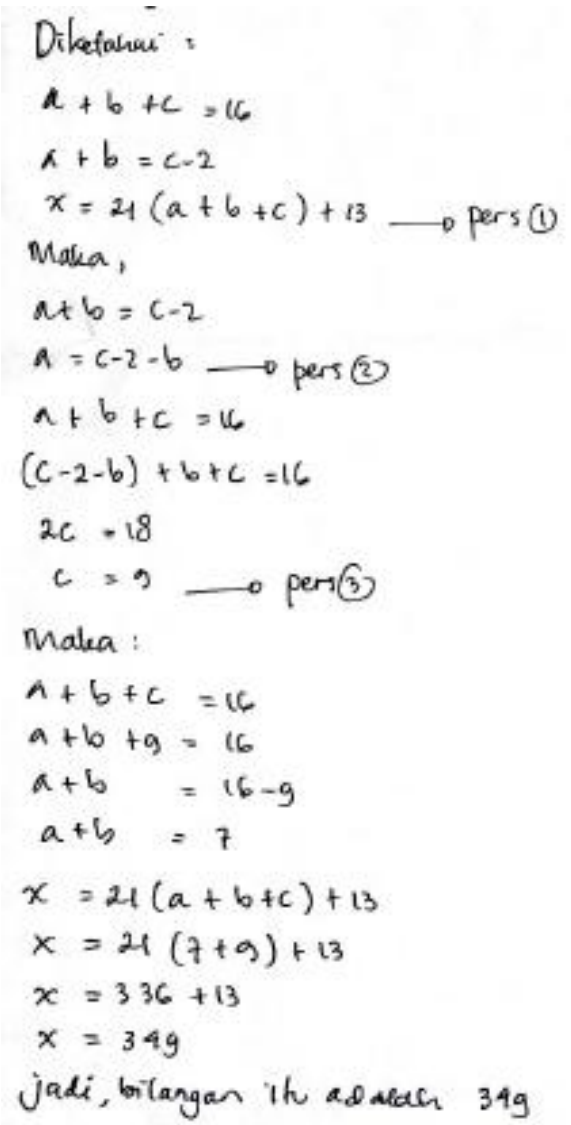

\section{Gambar 5. Jawaban Subjek B Hanya Menggunakan Cara Yang Diberikan Guru}

Berdasarkan hasil wawancara, pada tahap proses ini subjek B tidak memenuhi kriteria dikarenakan kurang memahami materi yang disampaikan secara daring. Sehingga subjek B tidak bisa menjawab soal sesuai dengan materi yang diberikan meskipun mengunakan cara lain. Meskipun pada tahap proses tidak memenuhi kriteria, subjek B mampu dalam skema. Dalam (Mulyono, 2011) menyatakan jika peserta didik dikatakan memenuhi dalam tahap ini ketika mampu mengubah bahasa verbal menjadi bahasa atau model matematika.

Sedangkan pada peserta didik berkemampuan rendah hanya mampu memberikan inti dari materi terkait halhal mendasar. Ketika memasuki soal yang menyajikan model SPLTV peserta didik kesulitan dalam membuat model matematikanya dan cenderung tidak mamnı menemukan himnınan fistem persamaan linier yang masing - masing persamaanaza juga bervariabel tiga

$$
\begin{aligned}
\text { Gambar 6. } & \begin{array}{l}
\text { Jawaban Subjek } \\
\text { Menunjukan } \\
\text { Aksi }
\end{array} \\
x, y, z & =16 \\
x+y & =z-2 \\
& =21-16+3 \\
& =336+3 \\
& =339
\end{aligned}
$$

Gambar 7. Subjek C Tidak Menemukan Hasil dengan Benar

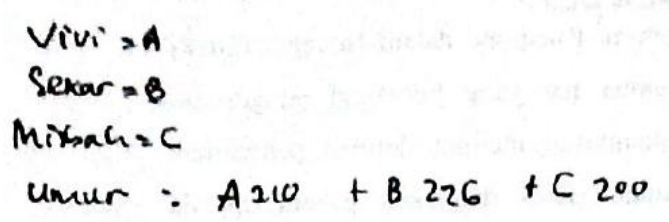

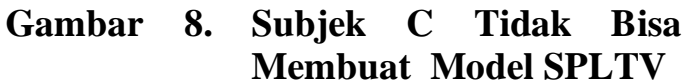

Berdasarkan hasil wawancara subjek $\mathrm{C}$ sudah berusaha untuk menyelesaikan soal yang diberikan. Akan tetapi himpunan yang diperoleh salah. Hal ini terjadi dikarenakan selama pembelajaran ia tidak memperhatikan sama sekali dikarenakan pembelajran yang selalu diberikan secara daring membuat semua pelajaran menjadi sulit dipahami. Penyampaian yang dilakukan oleh guru 
tidak bisa diterima secara langsung, sehingga peserta didik berkemampuan sepertinya juga akan mengalami hal yang sama. Subjek $\mathrm{C}$ juga mengaku tidak bisa membedakan lebih dari satu variabel sehingga tidak bisa menyelesaikan jika dihadapkan dengan persamaan yang memiliki dua atau lebih variabel.

\section{Simpulan dan Saran \\ Simpulan}

Berdasarkan hasil analisis, dapat disimpulkan bahwa ketiga subjek peserta didik MA Miftahul Huda Kepanjen memiliki kemampuan yang berbeda-beda dalam memahami konsep materi Sistem Persamaan Linier Tiga Variabel (SPLTV) berdasarkan teori APOS. Pada subjek A peserta didik mampu memenuhi semua kriteria APOS dalam memahami konsep. Sedangkan pada subjek B peserta didik tidak memenuhi kriteria proses. Sedangkan pada subjek $\mathrm{C}$ peserta didik hanya memenuhi kriteria aksi.

\section{Saran}

Berdasarkan kesimpulan yang diperoleh, setiap peserta didik dengan kemampuan berbeda-beda tentu sangat menentukan seberapa besar pemahaman konsepnya terhadap materi yang diberikan. Oleh karena itu penulis menyarankan agar guru selalu memperhatikan cara atau metode penyampaian materi pembelajaran baik luring maupun daring. Hal ini dikarenakan pemahaman konsep sangatlah penting untuk membantu peserta didik agar mampu menyelesaikan persoalan-persoalan yang diberikan.

\section{Daftar Pustaka}

Alifiani, A. (2017). Penerapan Model Pembelajaran NHT-TGT untuk Meningkatkan Motivasi dan Pemahaman Konsep Materi Matematika SMA. Jurnal Riset Pendidikan Matematika, 4(1), 11. https://doi.org/10.21831/jrpm.v4i1.13 100

Fitrianda, M. I. (2013). Digital Digital Repository Repository Universitas Universitas Jember Jember Digital
Digital Repository Repository

Universitas Universitas Jember.

Fuadi, R., Johar, R., \& Munzir, S. (2016). Peningkatkan Kemampuan Pemahaman dan Penalaran Matematis melalui Pendekatan Kontekstual. Jurnal Didaktik Matematika, 3(1), 47-54. https://doi.org/10.24815/jdm.v3i1.43 05

Harta, I., Yani Tromol Pos, J. A., \& Kartasura, P. (2014). Pengembangan Modul Pembelajaran untuk Meningkatkan Pemahaman Konsep dan Minat SMP. PYTHAGORAS: Jurnal Pendidikan Matematika, 9(2), 161-174.

http://journal.uny.ac.id/index.php/pyt hagoras

Jeheman, A. A., Gunur, B., \& Jelatu, S. (2019). Pengaruh Pendekatan Matematika Realistik terhadap Pemahaman Konsep Matematika Siswa. Mosharafa: Jurnal Pendidikan Matematika, 8(2), 191202.

https://doi.org/10.31980/mosharafa.v $8 \mathrm{i} 2.454$

Lestari, K. E. (2015). Penerapan Model Pembelajaran M-APOS Untuk Meningkatkan Kemampuan Pemecahan Masalah Matematis Siswa SMP. Jurnal Pendidikan UNISKA, 3, 45-52

Mulyono, M. (2011). Teori APOS dan Implementasinya dalam Pembelajaran. Journal of Mathematics and Mathematics Education, $1(1)$. https://doi.org/10.20961/jmme.v1i1.9 924

Najlasari, D. (2019). Analisis Kesulitan Matematika dalam Proses Pembelajaran Siswa. May, 1-6.

Ningsih, Y. L., \& Rohana, R. (2018). Pemahaman Mahasiswa Terhadap 
Persamaan Diferensial Biasa

Berdasarkan Teori Apos. Jurnal

Penelitian dan Pembelajaran

Matematika, 11(1). https://doi.org/10.30870/jppm.v11i1. 2995

Wahyuningsih, H., Nissa, I. C., \& Yuntawati, Y. (2019). Analisis
Kemampuan Siswa dalam Memahami Konsep Sistem Persamaan Linier Tiga Variabel (SPLTV) Berdasarkan Teori Apos Siswa Kelas X IPS 1 MA Tarbiyatul Mustafid Batu Rimpang. Media Pendidikan Matematika, 7(1), 36. https://doi.org/10.33394/mpm.v7i1.1 556 